\title{
The Role of Intentions in Determining Social Entrepreneurial Profile
}

\author{
María del Carmen Meza Téllez, Ignacio Ortiz Betancourt, Patricia Margarita Villar Sánchez, \\ Leidy Margarita López Castro and Jessica Andrea Muñoz Carrillo
}

\section{ABSTRACT}

In this research the entrepreneurial actions and intentions that drive university students to create social businesses and participate in an international competition were analyzed. The study was conducted during the training week of a social business competition in September 2019. The methodology was qualitative, with case studies in a group of twelve students whose projects were selected to compete at the semi-final round of an international social business competition. Interviews were applied to competitors which revealed the circumstances that encouraged them to address a social problem and develop a project with a solution which will be presented in an international stage. Simultaneously, an observation guide was applied for the interpretation of the emotional expressions (typical of social entrepreneurship) associated with their responses and finally, an electronic link was shared with participants for them to answer a validated instrument that measured the university entrepreneurial potential. Main findings indicate that entrepreneurial actions of the students to create a social business and present it in a competition in the form of a social business project rest on motives that vary from a personal origin to the collective, revealed from moments of inspiration and personal commitment to address a social problem and seeking a sustainable solution, designed from resources and personal skills in a very particular emotional atmosphere. Finally, a sum up from all inputs (surveys and direct observation) revealed that social entrepreneurial intentions lie on a positive attitude, strong enterprise convictions and high desirability for becoming an entrepreneur and contribute to solve social problems.

Keywords: Entrepreneurial intentions, entrepreneurial learning, higher education, social entrepreneurs.

\section{INTRODUCTION}

Highlight The study of entrepreneurial learning has been eclipsed by the analysis of factors that enhance entrepreneurs or its contribution to employment and economic growth; entrepreneurship has been considered for the last decade as tool for empowerment and social welfare. As mentioned by [1], entrepreneurial learning as a study field is in its early stage and there is no clear consensus about the constructs that define it as a category; also, as there are many factors that could affect entrepreneurial learning such as the social context or the syllabus that led the pathway to new entrepreneurs, it is hard to identify which are the most relevant.

Also, the new roles and features of entrepreneurs have widened the ways of understanding their learning process, considering that traditional for-profit entrepreneurs now interact with social entrepreneurs which develop projects by different schemes but prioritizing social outcomes. This change places a series of questions that could lead further research about entrepreneurial profiles, intentions, and motivations to start a project.

\author{
Submitted : March 3, 2021 \\ Published : March 24, 2021 \\ ISSN: 2507-1076 \\ DOI: $10.24018 /$ ejbmr.2021.6.2.794 \\ María del Carmen Meza Téllez \\ Faculty of Administration (Veracruz), \\ Universidad Veracruzana, Mexico. \\ (e-mail: cmeza@ uv.mx) \\ Ignacio Ortiz Betancourt* \\ Faculty of Administration (Veracruz) \\ Universidad Veracruzana, Mexico. \\ (e-mail: igortiz@uv.mx) \\ Patricia Margarita Villar Sánchez \\ Faculty of Administration (Veracruz), \\ Universidad Veracruzana, Mexico. \\ (e-mail: pvillar@uv.mx) \\ Leidy Margarita López Castro \\ Faculty of Administration (Veracruz), \\ Universidad Veracruzana, Mexico. \\ (e-mail: leilopez@uv.mx) \\ Jessica Andrea Muñoz Carrillo \\ Faculty of Administration (Veracruz), \\ Universidad Veracruzana, Mexico. \\ (e-mail: jessica.mc ${ }^{@}$ outlook.es)
}

*Corresponding Author

Despite this ambiguous scenario, entrepreneurial learning has acquired relevance among researchers from public agencies and higher education institutions since there is an agreement about the positive impact of education to provide theoretical foundations and boost skills that enhance entrepreneurs [2]. For this reason, entrepreneurship training has become a priority of the educational system [3], since society needs more professionals capable of create employments and drive innovative processes which solve social issues. Also, [4] state that university training produces a positive impact in entrepreneurial potential and increase students' confidence to undertake projects, empowering them to initiate an entrepreneurial pathway.

Nevertheless, even when university training is key to promote entrepreneurship, intention is probably the most relevant factor that turn entrepreneurial ideas into projects. In this regard, [5] remark that as entrepreneurs are nowadays considered as "change agents" for their contribution to economic growth, self-employment, and innovation, it is necessary to design efficacious plans to handle the employability among youth population. Then, it is important to detect those factors that incite entrepreneurial intention. 
Likewise, [6] mention that entrepreneurial intentions are key to develop a new business, but it is also relevant to explore which factors influence these intents. Besides, they find a gap among between the positive perception among students for entrepreneurship and their low level of intention; so, it is worth studying the "entrepreneurial learning process" [7]-[9].

Additionally, [10] point out that as an emerging field of study, there are several approaches to address this topic such as the design of indicators to measure the effect of emotions or the intention-to-behavior transition.

Considering the relevance of entrepreneurship nowadays and the state of this topic, a study question is posed: Which are the factors that drive entrepreneurial intentions among a group of university students that take part in an international competition?

\section{RESEARCH METHODS}

\section{A. Methodology}

This research was developed under the qualitative paradigm since the phenomenon is analyzed in its context and individuals shape their reality while they participate on it [11]. Besides, the case study scheme [12] under and exploratory method was applied considering that this work is an empirical investigation that searches a current situation in its real framework, particularly when boundaries between situation and context are not evident. Also, as facts were captured as the event was developing, this inquiry is considered as live under the classification criteria. The phases of the methodological were followed as proposed by [12]: case study design; preparation of data collection, data collection, case study analysis, and report preparation.

\section{B. Theoretical Framework}

Despite the study of social entrepreneurship started gaining interest during the seventies and eighties, it was in the nineties when this issue gained awareness from public agencies and educational institutions [13] and the beginning of twenty-first century took it to new dimensions, especially in the educational scope, generating diverse publications and studies focused in this area. Also, the raising popularity of successful social entrepreneurs such as Muhammad Yunus (notable founder of Grameen Bank and 2006 Nobel Prize Winner) and Jeffrey Skoll (former Ebay's President and founder of the Skoll Foundation) contributed to spread the social entrepreneurship culture, producing a trend that, according to the [14] in 2019 reached 622 million individuals in nearly two hundred countries, improving social welfare, and living standards.

As its main feature, social entrepreneurship is recognized by its desire for creating social gains rather than maximizing investors' profits, although this does not mean that the financial sustainability of enterprises is not necessary. Hence, this type of entrepreneurs could ignite large-scale benefits by providing solutions that solve social needs, creating jobs, empowering people, and lowering poverty levels. In addition, social entrepreneurs are considered as individuals who develop innovative ways to create social gains, regardless of if they operate as non-profit, for-profit, or governmental organizations [15].

As for the factors that trigger the intentions of social entrepreneurs, these could be related to the Theory of Planned Behavior [16] and the theorical contributions of [17]-[18] which are focused on the study of social learning. In recent years, [19]-[21] have studied the role of intentions among university entrepreneurs, finding out that personal factors as self-esteem \& confidence and external components like the context in the country of residence and academic training are important to encourage entrepreneurial intentions.you submit your final version, after your paper has been accepted, prepare it in two-column format, including figures and tables.

\section{Study Subjects}

The field research stage was performed during an international social business competition held in September 2019, twelve participants were enquired through a personal conducted interview and later answered an online survey; it is important to mention that more participants were asked to freely contribute with this research but decided not to. During the interview, a direct observation process was conducted to register participants reactions and some off the record expressions. Answers provided were registered, processed, and analyzed to answer the study question: Which are the factors that drive entrepreneurial intentions among a group of university students that take part in an international competition?

As a preliminary proposition, next premise is stated: students get involved in a social business that they present in an international competition grounded on their optimism, self-confidence, and enterprise intentions in order to comply with society and for their confidence and ability to find an acceptable solution in a comfortable environment.

\section{Objectives}

This study's main goal is to describe the factors that ignite entrepreneurial intention (inspiration, motives, commitments to the problem) and potential university entrepreneur (entrepreneurial potential, realism, optimism, desirability, perceived control, business intentions) that lead a university student to create a social business and participate in an international competition.

\section{E. Categories of Study}

This study considers one category of study "entrepreneurial profile" which is the result of two dimensions: entrepreneurial intention and entrepreneurial potential.

\section{F. Sources of Information}

Data were obtained from personal interviews and a questionnaire answered by competitors, also a direct observation process was conducted while these instruments were applied to identify other qualitative aspects not captured in these research tools.

\section{RESULTS}

This section is deployed in three steps, each one corresponding to one source of information. Then, discussion of joint main findings is provided. 


\section{A. Direct Interviews}

The method followed to apply this instrument is described next: topics (according to the specific objectives of the research) that are questioned are determined: country of origin; gender; background; commitment to the problem and attention to the solution. After interview ended, the notes of the interviews conducted by the field researcher are transcribed; then, content of the answers indicated is analyzed, remarking those phrases or sentences with a meaning relevant to the investigation.

Later, the sample is classified according to its origin and gender. Next, categories were identified for the topics: background, commitment to the problem and attention to the solution. The categories for background are social class; parent occupation; occupation of the interviewee (student / professional); the categories for commitment to the problem are: moment of inspiration; motivation to address the problem; commitment to the problem; The category to address the solution of the problem is: description of the resources (external / internal), capabilities (external / internal) and actions (own / others) used to address the problem at first (first solution).

Starting with the analysis of participants' background, twelve competitors from five countries were considered for this study. Mexico was the country with the largest number of participants $(5=41.6 \%)$ followed by Vietnam $(3=25 \%)$, Argentina $(2=16.7 \%)$, Bangladesh $(1=8.3 \%)$ and Australia $(1=8.3 \%)$. About gender, $83.3 \%$ were male and $16.7 \%$ female.

As for the social class, $50 \%$ of them were found to belong to the middle class, $16.7 \%$ to the upper-middle class, and $16.7 \%$ to the working class, $8.3 \%$ to the upper class and $8.3 \%$ to the lower class. Regarding their parents' occupations, it was found that in two cases $(16.7 \%)$ both parents are entrepreneurs; in two other cases $(16.7 \%)$ both parents are employees of the army and in two other cases $(16.7 \%)$ both parents work in the construction sector. On the other hand, it was found that in one case $(8.3 \%)$ the parents are teachers; in another $(8.3 \%)$ they are both professionals and entrepreneurs; Similarly, in two cases $(16.7 \%)$ it was found that one of the parents is employed and the mother is a housewife and volunteer in a social cause. Only in two cases (16.7\%) participants did not provide an answer.

As for the participants' academical training, it was found that 6 of them $(50 \%)$ came from the business area and four at the same time are entrepreneurs, $3(25 \%)$ are engineers, 1 $(8.3 \%)$ study Economics and $2(1.7 \%)$ are still at college.

For the second section "Commitment to the problem", three categories were determined: the moment of inspiration, the motivation to address a social problem and the commitment to the problem itself. It is important to notice that quotations marks are used to cite relevant portions of participants' answers.

As for their source of inspiration, we sought to understand, from the words expressed, the theme associated with its emergence within the person. The results were the following: 3 cases associated with the concern for the environment were found: the environmental crisis as priority issue nowadays; food waste in the world and deforestation; 3 other cases were associated with the aim of helping a colleague in solving a world problem:... "he really wanted to do something else to leave that feeling of" not been giving enough "; 2 cases were related to the issue of poverty... "the needy people is my people"... ; ..."I am a survivor of poverty, ignorance, analphabetism, violence and crisis "; 2 other cases were associated with the growing public health issue... "Mexico City, a City full of pollution and also where the $30 \%$ of the population has obesity"... and "I was able to see that kids don't have a nutritious snack option "; and 2 cases addressed the problem of injustice towards women... "I realized that equality for women doesn't just exist in labor market".

Then, items related to aspects that motivated them to attend a social problem, following a procedure similar to the previous one, showed that 7 respondents were motivated to being useful to others who encountered a problem..."money does not don't fill me up at all "; I grew up in a voluntary environment ... "; ..." he realized that there was a way to help women not suffer so much the lack of sexual security ";" ... he discovered that he needed to do something,. .. "I will probably not solve the problem in the blink of an eye", but I want to contribute".

In other cases, participants' acts revealed their motivations, for example: awareness to see a social problem, but at the same time the opportunity to be part of the solution; respond to the call of a partner about the conditions of inequality of women; work as a Social Development Leader in his mother's international volunteer organization; help a partner who has encountered a social problem and apply his experience from this competition previous edition; also, 2 of the interviewees were motivated by the grade of inequality in society; 2 more were moved by the gender disadvantages just for being a woman ... answering a colleague's call about conditions of female inequality and 1 the commitment to change the world ... "I was committed to doing something that could change the world at least a little bit".

For the segment "personal commitment to the problem", understood as: What was he committed to when he addressed the problem? And continuing with the same procedure of previous interpretation (words-associated subject and words - associated actions that were mentioned) it was found that the interviewed mentioned: commitment to find a sustainable solution to the problem by "finding the best solution to the problem"; practice your social business achievement "I really believe that by educating the next generations I will be able to help solving social issues"; create a nutritious snack option for children and "offer a solution for high levels of food waste and on the other hand deforestation in your country".

Also, it was mentioned the need to engage to solve a problem in their context ... "how to solve this problem comes from my own life"; dedication to act to solve the problem being congruent with my person ... start to investigate more and more on the subject".

Commitment to find an equitable solution to the problem: offer a sexual security solution for women; Work to develop a solution that consists of "conscious clothing ... and improve fair wages for women workers. Commitment to offer a solution to a problem, without the need of someone who has previously requested: "I am raising my son and I return to my neighborhood with the need to save only one life if I can change only one. my whole life was worth it".

After asking participants about their background and motivation, third section of the interview concludes with the 
question: How was the first solution formulated? Respondents' responses were reviewed (most of the two or more) and classified into the following groups: knowledge and skills (learned in during academic career) were the most popular answers which were mentioned by seven participants (58.3\%); using the competition's methodology (3 mentions), understanding the problem ( 2 mentions), direct observation and then using resources from the closest context (2 mentions), their experience as an entrepreneur ( 2 mentions), join a colleague's project ( 2 mentions). Next answers were cited only once: research the problem and then look for the solution; communicate the problem and spread the message to all interested parties; develop a prototype; advice from teachers and professionals.

\section{B. Direct Observation}

As part of the field research, the interviewer conducted all interviews at the competition venue facilities during different times of the day from September 24 to 30. At the beginning of the competition, the event organizer presented the interviewer to participants and indicated that she would conduct interviews with some of them who would be chosen randomly during those days.

This direct observation process registered two types of annotations related to the participants' affective part on a social problem (positive or negative feelings) and on the other hand their attitudes towards the competition itself (human attitudes).

Regarding the first direct observation of the emotional part (feelings) of the participant towards the social problem, the feelings expressed in relation to the problem are considered since the interviewed started exposing his background, his commitment to the problem (moment of inspiration, motivation, and commitment to obtain the solution of a problem) and how it structures its first solution. From all answers, next classification was made "positive feelings: euphoria, admiration, affection, optimism, gratitude, satisfaction, love, and pleasure; negative feelings: sadness, indignation and impatience. It was observed that the expressions associated with positive feelings were 22 while those related to negative feelings were only 3 .

\section{Online Survey}

The questionnaire on the potential university entrepreneur is an instrument developed and validated by the Chair of Entrepreneurs of the University of Salamanca (Spain) and measures 5 aspects: realism, optimism, desirability, perceived control, and enterprise intentions. Items focused on realism cover topics such as self-control in daily and troubled situations. Later, optimism section addresses issues such as leadership skills, risk aversion and facing challenges. Then, desirability focuses on perception for becoming social entrepreneur. Perceived control section inquiries on behavior and resources management to land a social project. Enterprise intentions section refers how evidenced are participants' intentions to create their own companies or how they support others in achieving that goal.

The application of this research instrument was done online; the link was shared with the members of the sample and results were processed in a database; interpretation was developed in a general way, remarking the most important findings in each section.

Each section of this research instrument showed consistent results regarding a positive trend on social entrepreneurship. Realism section showed that all participants are aware of their country's socioeconomic environment and local issues which affect their lives. Also, they are conscious of their capabilities and skills to face hard situations and manage groups to concrete ideas. As for the optimism items, the entire sample showed a very optimistic profile since they understand their reality but do not fear assuming challenges to succeed in life. As for participants' Desirability to become social entrepreneurs, a positive inclination was detected since all of them aim to start their own business, despite all dares and barriers that they might face. Also, it was revealed a common goal among respondents to become their own boss and taking control on their lives by assuming important decisions.

Regarding items on Perceived control, participants indicated being able to change plans if necessary, not sticking to projects which are no longer productive or to team members who do not commit to social business goals. Thus, participants can take objective and rational decisions to pursue their projects' success, proving leadership skills.

About Enterprise intentions section, answers were very consistent since all participants have strong loyalty to their social entrepreneurship projects and consider that they have both knowledge and skills to start a business which will be rewarding; also, they are willing to inspire others to follow them in the social business culture.

\section{Discussion}

This section verifies similarities and differences among the results among data sources and analyze the information to establish main findings. Regarding the comparative analysis between the interviews and the online questionnaire, it was observed that students whom parents have entrepreneurial, or business experience are propense to become entrepreneurs; also, it was detected that almost all participants which were surveyed already had labor or entrepreneurial experience; then, competitors are highly engaged trying to solve social problems.

As for factors which stimulated social entrepreneurship intentions, interviews analysis reflected the existence of two main groups: those who experienced a social problem since childhood and suffered from it and, on the other side, contestants that are conscious of situations that affect their community and want to contribute to solve them. Both can be considered as agents of change. These findings are related to Realism and Desirability sections which results reflected that participants are aware of their context and want to create solutions to improve social welfare.

Regarding how contestants sketched out their projects, answers indicated the relevance of academic training at high education institutions or special events such as this competition. This is aligned to Optimism and Perceived control sections results since training is a key element to produce higher confidence levels by providing knowledge and contributing to skills development which are essential to enforce social entrepreneurship ideas.

Also, Enterprise intentions and Perceived control are related considering that contestants expressed strong 
commitment to start their own business no matter the hard situations they could face and how complicated decisions might have to take to pursue their projects success.

As for direct observation findings, it is important to mention that dominance of positive feelings among surveyed perfectly aligns to Optimism results. Also, the context in which this research was developed could have contributed to increase positivity and optimism among contestants since all of them were experiencing the result of months of hard-work and commitment to their projects.

\section{CONCLUSION}

The study of intentions in determining entrepreneurial profiles is one of the most growing research issues during recent years. As a barely studied topic in the Mexican context, this work aimed to identify factors that ignite intentions among entrepreneurs which participate in an international competition and how these contribute to shape their entrepreneurial shape. Results from this qualitative research were obtained from three sources. Online surveys revealed a high-level of realism, optimism and perceived control among participants and elevated desirability and enterprise intentions. These outcomes were consistent with interviews results and attitudes detected during the direct observation process. Main findings showed that family background, proximity to problem and self-confidence are important elements that propel entrepreneurial intentions.

This work is considered as the basis of an exercise that must be replicated in a larger sample to obtain more information and thus results that lead to generalizations on this topic. In addition, it allowed detecting the following lines for future research: the socioeconomic level of the participants and the strength of their business intentions; and the implementation rate of the projects participating in the competition by type of university (public or private) and the factors that influence it. Besides, it will be enriching to identify if the participation rate in this investigation increases once the competition ends and not during its development.

\section{REFERENCES}

[1] Royo, M., Sarip, A., \& Shaari, R. (2015). Entrepreneurship traits and social learning process: an overview and research agenda . ProcediaSocial and Behavioral Sciences, 745-753.

[2] Matlay, H. (2006). Researching entrepreneurship and education Part 2: what is entrepreneurship education and does it matter? Education + Training, 704-718.

[3] Paternina, J. (2018). El emprendimiento escolar, una estrategia deidentificación de talentos excepcionales. Espacios.

[4] Sepúlveda, J., Valenzuela, A., \& Galvez, F. (2019). Intención emprendedora deestudiantes de la carrera de Auditoríade la Universidad Católica del Maule(Chile). Espacios.

[5] Koe, W.-L., Rizal, J., Abdul, I., \& Ismail, K. (2012). Determinants of Entrepreneurial Intention Among Millennial Generation. Procedia Social and Behavioral Sciences, 197-208.

[6] Ozaralli, N., \& Rivenburgh, N. (2016). Entrepreneurial intention: antecedents to entrepreneurial behavior in the U.S.A. and Turkey. Journal of Global Entrepreneurship Research volume.

[7] Linton, G., \& Klinton, M. (2019). University entrepreneurship education: a design thinking approach to learning. Journal of Innovation and Entrepreneurship volume.

[8] Royo, M., Sarip, A., \& Shaari, R. (2015). Entrepreneurship traits and social learning process: an overview and research agenda . ProcediaSocial and Behavioral Sciences, 745-753.
[9] Rennemo, Ø., \& Åsvoll, H. (2019). Existential learning: dialogues and places to be(come) in entrepreneurial Ba practice. Journal of Innovation and Entrepreneurship.

[10] Nabi, G., Liñán, F., Fayolle, A., Krueger, N., \& Walmsley, A. (2017). The Impact of Entrepreneurship Education in Higher Education: A Systematic Review and Research Agenda. Academy of Management Learning \& Education.

[11] Krauss, S. E. (2005). Research Paradigms and Meaning Making: APrimer. The qualitative report.

[12] Yin, R. (2003). Case Study Research: Design and Methods. SAGE.

[13] Braunerhjelm, P., \& Stuart, U. (2012). Social entrepreneurship- a survey of current research. Swedish Entrepreneurship Forum.

[14] Schwab Foundation for Social Entrepreneurship. (2020). 2020 Impact Report.

[15] Austin, J., Stevenson, H., \& Wei-Skillern, J. (2012). Social and commercial entrepreneurship: same, different, or both? Revista de Administração, 370-384.

[16] Ajzen, I. (1991). The theory of planned behavior. Organizational Behavior and Human Decisions Processes, 179-211.

[17] Bandura, A. (1971). Social Learning Theory. General Learning Corporation.

[18] Bandura, A. (1999). A social cognitive theory of personality. En L. Pervin, \& O. John, Handbook of personality (págs. 154-196).

[19] Sánchez, J. C. (2009). Aprendizaje social e intenciones emprendedoras: un estudio comparativo entre México, España y Portugal. Revista Latinoamericana de Psicología, 109-119.

[20] Sánchez, J. C. (2011). University training for entrepreneurial competencies: Its impact on intention of venture creation. International Entrepreneurship and Management Journal, 239-254.

[21] Sánchez, J. C., Lanero, A., \& Yurrebaso, A. (2005). Variables determinantes de la intención emprendedora en el contexto universitario (Determinant Variables of the Entrepreneurial Intention in the University Context). Revista de Psicología Social Aplicada. 